\title{
Community based maize seed production in the hills and mountains of Nepal: A review
}

D Sapkota and S Pokhrel

Crop Development Directorate, Department of Agriculture, Nepal

\begin{abstract}
A review on the community based maize seed production and technology dissemination in Nepal was made in 2009 to know the seed production situation and technology dissemination approaches. Twenty three open pollinated maize varieties and one hybrid were released by the Nepal Agricultural Research Council (NARC) up to 2009. A number of stakeholders were involved on improved technologies dissemination, seed production and marketing. Approaches for technology dissemination include district seed self sufficiency program (DISSPRO) and community based seed production (CBSP) program. About 4500 ton of cereal seeds annually has been producing from these approaches. Approach include subsidies on source seeds, creation of revolving funds, group/co-operative formation, their mobilization for participatory varietal selection (PVS), demonstrations, training, informal research and development (IRD) kit distribution and exchange visits. In community level, activities such as community based seed production approaches, particiapatory technology development, verification and dissemination for sustainable seed production and marketing has been taken place.
\end{abstract}

Key words: IRD, Seed Technology, DISSPRO, PVS, CBSP

\section{Introduction}

Maize (Zea mays) is the major traditional cereal crop in rain-fed ecosystem of the hills and mountain which covers about $81 \%$ (mountain- $10.45 \%$ and hill- $70.23 \%$ ) of the total cultivated area (MoAC, 2009). Among cereals, it contributes about $26.8 \%$ of the total food requirement with a vital role in the livelihood of the people living in the hills and mountains of the country. It is cultivated as food, feed and fodder on slopping bari land (rainfed upland) in the hills. Maize is grown under rainfed conditions during the summer (April-August) as a single crop or relayed with millet later in the season. In the terai, inner-terai, valleys, and low-lying river basin areas, maize is also grown in the winter and spring with irrigation. More than two third of the maize produced in the mid hills and high hills is used for direct human consumption at the farm level. The ratio of human consumption to total production is higher in less accessible areas. In terai, less than 50\% of the maize is used for human consumption and a major part of the production goes to the market (Paudyal et al, 2001). Maize contributes about $6.88 \%$ of the total agricultural GDP supplied to the nation (MoAC, 2008). In 2008/2009, maize was grown in about 875,428 ha which represents $25.6 \%$ of the total area planted to cereals in Nepal. In the same period, 1930670 metric tons of maize was produced, representing about $23.8 \%$ of Nepal's total cereal production. In the recent years, maize has come up as new and promising cash crop in the terai region due to growing number of demand in feed industry sectors. Maize demand has been constantly growing by about $5 \%$ annually throughout in the last decade. The current maize growing area of Nepal requires $17508 \mathrm{mt}$ of seeds at $20 \mathrm{~kg} / \mathrm{ha}$ but the seed replacement rate is very low (5.98\%). Maize seed production within the country is about $1050 \mathrm{mt}$ per annum (CDD, 2009). Annual hybrid maize seeds import from India is estimated $575 \mathrm{mt}$ per year. So, there is a strong need of sustainable community level seed production program with an appropriate production approach. 


\section{Methodology}

Review was made based on the secondary information from different sources of publications through CDD, MoAC, NSB, NARC/NMRP and electronic media.

\section{Area, production and productivity}

The area, production and productivity of maize are slowly and constantly increasing since 1984 in Nepal (Figure 1) However, the production of maize is low compared to neighboring countries (India 2.32, Bangladesh 6.01, Pakistan 3.61, Chaina 5.56, Myanmar 3.2, Bhutan 2.75 t/ha, FAO 2008) and production increase is attributed to the area expansion in less suitable terrain, declining soil fertility, and the sluggish adoption of improved management practices. The percentage increase in area, production and productivity of the maize in 2009\10 compared to $1984 / 85$ is $47.8,135.4$ and $55.6 \%$, respectively (MoAC, 2009). Though, bulk of the maize area (80.6\%) lies in hills and mountains of Nepal, the productivity of hills $(2201 \mathrm{Kg} / \mathrm{ha})$ and mountains $(2064 \mathrm{~kg} / \mathrm{ha})$ is rather less than the national average $(2205 \mathrm{Kg} / \mathrm{ha})$ (Table 1 and 2$)$.

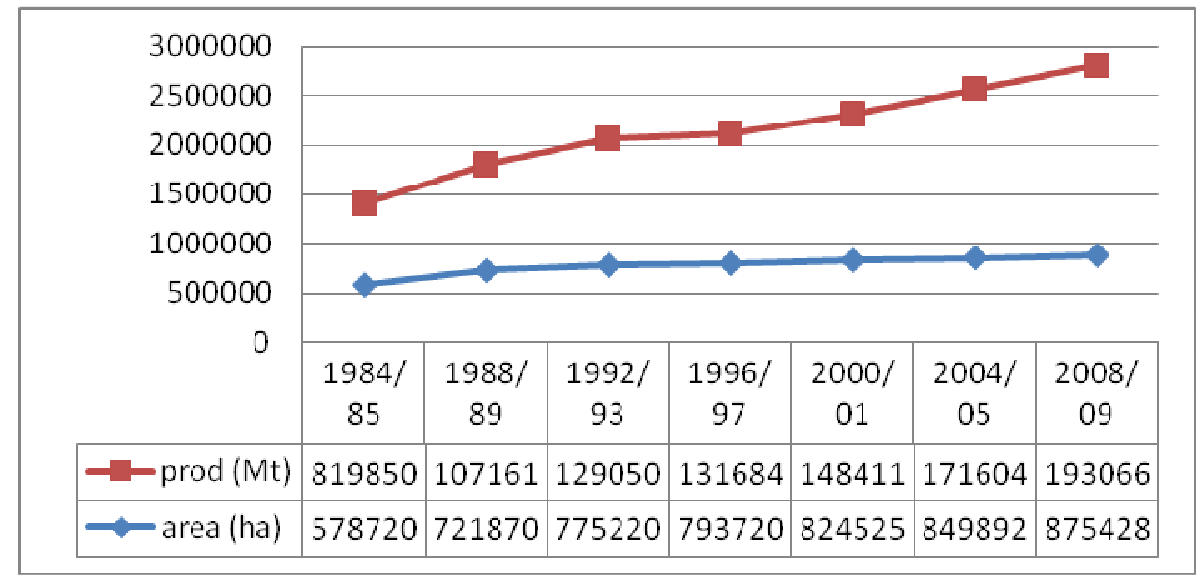

Figure 1. Maize production trend in Nepal

Source: (MoAC, 2009)

Table 1. The area, production and productivity status of maize in hills of Nepal in 2008/09

\begin{tabular}{lccc}
\hline \multicolumn{1}{c}{ Region } & Area (ha) & Production (mt) & Productivity (Kg/ha) \\
Eastern hills & 142599 & 301542 & 2115 \\
Central hills & 137897 & 305986 & 2219 \\
Western hills & 209388 & 515201 & 2461 \\
Mid-western hills & 103829 & 193176 & 1861 \\
Far-western hills & 21130 & 37303 & 1765 \\
\multicolumn{1}{r}{ Total } & $\mathbf{6 1 4 8 4 3}$ & $\mathbf{1 3 5 3 2 0 8}$ & $\mathbf{2 2 0 1}$ \\
\hline
\end{tabular}

Source: (MoAC, 2009)

Table 2. The area production and productivity status of maize in mountains of Nepal 2008/09

\begin{tabular}{lccc}
\hline \multicolumn{1}{c}{ Region } & Area (ha) & Production (Mt.) & Productivity (Kg/ha.) \\
Eastern mountains & 40809 & 85804 & 2103 \\
Central mountains & 29635 & 66790 & 2254 \\
Western mountains & 703 & 1160 & 1650 \\
Mid-western mountains & 9809 & 16184 & 1650 \\
Far-western mountains & 10540 & 88890 & 1792 \\
\multicolumn{1}{c}{ Total } & $\mathbf{6 1 4 8 4 3}$ & $\mathbf{1 8 8 8 2 8}$ & $\mathbf{2 0 6 4}$ \\
\hline
\end{tabular}

Source: (MoAC, 2009) 


\section{Maize research and extension}

Varietals research and extension activities are the keys for the technology generation and transfer. Efforts are made continuously on the development of high yielding and high demanding varieties and there are altogether 23 maize varieties released including one hybrid. Aside from this, seven maize varieties have been denotified from the list since 1960 (Bhatta and Bajracharya, 2008, NSB 2009). Efforts are equally underway to develop hybrids and protein rich maize varieties to further improve maize productivity and nutrition. Technologies transfers are underway through different approaches like DISSPRO, CBSP with PVS, under the extention umbrella of Department of Agriculture (DoA) and Non Government Organizations (NGOs) and Community Based Organizations (CBOs).

\section{Existing approaches of technology dissemination}

Technology dissemination is underway through different community based approaches mainlyDISSPRO, CBSP and PVS. Community mobilization through formation of group and cooperatives and technology transfer through the agriculture extension education (demonstrations, training, mini-kit/IRDkit and visits) are keys to increase technology adoption and increase food production.

\section{District seed self sufficiency program (DISSPRO)}

DISSPRO for the first time was envisaged in the Ninth Five Year Plan (1998/99 to 2001/03). Basic underlying principle of DISSPRO is to encourage and strengthen local level seed production and marketing to meet local and district level seed demand and, develop small scale seed entrepreneurship and facilitate the development of huge seed market in future; create awareness about the quality seed among the farmers; disseminate and multiply newly released varieties. Technology dissemination programs including training, $25 \%$ subsidy in the source seed, provision of seed fund and seed revolving fund of rupees five thousand to sizty thousands, respectively for each group and provision of two hundres rupees per ha for control of insects pests are major support programs. Formation and strengthening of farmers' groups to produce quality seed of desired verities and in required quantity is a major policy strategy of DISSPRO. To assure supply of source seed as per of the demand for which a seed balance sheet is prepared each year. It is becoming a very effective approach for seed sufficiency at local level. For the last two years, CDD is implementing a more intensive package of support for the commercial scale seed production in different 13 districts (11 terai and 2 hill) in 500 ha of area. This support package includes revolving funds upto sixty thousand rupees, seed processing and seed structure each upto fifty thousand rupees per group of farmer/cooperatives. 


\section{Implementation status of DISSPRO}

Sixtythree districts in hills and terai in Nepal adopted DISPRO program by utilizing available funds in the districts and central supports (technical and financial) from Crop Development Directorate. Annual seed production under DISPRO program on cereals, pulses and oilseed increased to $4000 \mathrm{mt}$ in 2009 (CDD 2009). Above figure of seed production was obtained from 28 districts out of 63 districts where DISPRO was launched.

\section{Lesson learned from a decade long DISSPRO}

- Supply driven (e.g. identification and seed multiplication of farmers' preferred varieties) program

- Scarcity of source seed of major cereals especially rice, oilseed and pulses

- Existing seed production technology dissemination system is not sufficient

- Seed quality control mechanism is not easy and effective

- Participation of stakeholders is encouraging

- Support for community based infrastructure from the government as well as private sectors/NGOs is nominal

- $\quad$ Seed marketing and market information system is very sluggish

- Strengthening of farmers' groups and farmers' cooperatives needs to be incorporated in the program and

- Agro-vets and seed traders' involvement for sustainable seed marketing is felt

\section{Community based seed production (CBSP) in Maize}

In 1999, Hill Maize Research Program (HMRP)/ CIMMYT for the first time worked with the DoA/ CDD to improve food security through increased maize production in the four hills and mountain districts of Nepal. In the second phase (year2004-2008) number of districts was increased to 11 for the same program by HMRP. After successful completion of the first and second phases, third phase of this project (2008 to 2010) has been implementing emphasizing the technology transfer to the poor and socio-economically disadvantaged communities in the hills and mountains in Nepal (NMRP 2008). CDD in collaboration with hill maize research program (HMRP/CIMMYT) and some non-governmental agencies are executing community based seed production (CBSP) program in maize in 25 hill and mountain districts. Participatory varietals selection and participatory technology development (PTD) using mother/ baby trail concept under CBSP are major technical interventions.

In 2007, $105 \mathrm{mt}$ of maize seed was produced from 11 districts while for the for the year 2008, it was 243 $\mathrm{mt}$ from 150 ha area and in 2009, it was $427.5 \mathrm{mt}$ from 231 ha from 25 districts (CDD, 2009a).

\section{Lesson learned from CBSP}

- A cheapest and successful intervention for sustainable food production

- Location specific maize varieties identified and technology generated through PVS and PTD

- Quality seeds produced and supplied at grass root level

- Participation of the multi- stakeholders in maize technology research and extension create enabling environment to realize the interest of each actor in a coordinated way

- PVS/ CBSP has increased access of the poor, women and disadvantaged groups for the technology and inputs

- Focus on the marketing and development of community structures for seed storage and marketing are insufficient

- Enterprising community groups in seed production, processing, storage and marketing are still weak in most of the cases 
- Increase in maize yield by $17 \%$ was realized in DoA/ CDD projects which areas mainly due to use of the quality seed of the improved variety and changes in technology

- Through PVS (mother-baby trial approach) farmers preferred varieties were selected and these were put into CBSP which facilitated the availability of the quality seed to the farmers.

- Rampur Composite, Manakamana 1, Manakamana 3, Deuti, Shitala varieties were released by NARC which has helped to increase maize production in the country

\section{Conclusion}

Despite four decades of endeavor towards maize production improvement the progresses are insignificant. The national annual seed replacement rate (SRR) for maize is only $5.98 \%$ and the national average productivity is $2205 \mathrm{Kg} / \mathrm{ha}$. The seed supply from the public sector for maize is less than $1 \%$ and adoption of the improved maize varieties is very low. DISSPRO was designed to transfer seed production technologies their by producing quality seeds and marketing at the community level. CBSP works as that of DISSPRO and it could be regarded as modified and improved version of DISSPRO. The main beauty of this approach is that it is cost effective, have good community participation and empower the disadvantaged groups. PVS has been prooved as an important approache and tool for variety selection (technology development) and technology verification So integration of all these approaches could be the best effective for particiapatory technology development, verification and disseminationof sustainable seed production and marketing.at community level. 


\section{References}

Bhatta MR and J Bajracharya. 2008. New approaches on varietal research and improvement at the national level: present status and future prospectives harmonizing the quality seed supply. In: Shrestha R.P. and M. Thapa (Eds).2008. Proc. fourth national seed seminar. 19-20 June 2008. Lalitpur, National Seed Board (NSB), Ministry of Agriculture and cooperatives (MoAC).

CDD. 2008. Proceedings of the regional interaction workshops of the seed producers and seed traders in Nepal, Western Development Region. 7 April 2008. Bhairahawa. Crop Development Directorate(CDD), Department of Agriculture (DoA).

CDD.2009. Annual progress report 2065/66 (in Nepali). Crop Development Directorate, Hariharbhawan, Lalitpur Nepal

CDD.2009a. Annual progress report 2009. HMRP/CIMMYT, Crop Development Directorate, Hariharbhawan, Lalitpur Nepal.

FAO (Food and Agriculture Organization). 2008.www.fao.org/crop/statistics/en download on 20th July 2008

MoAC (Ministry of agriculture and Cooperatives). 2008. Selected indicators of Nepalese agriculture and population. Agribusiness promotion and statistical division/Gender equity and environment division, Ministry of Agriculture and cooperatives (MOAC), Singha Durbar, Kathmandu, Nepal.

MoAC (Ministry of agriculture and Cooperatives).. 2009. Statistical information on Nepalese agriculture (2008/09), Agribusiness promotion and statistical division,Ministry of Agriculture and Cooperatives (MOAC), Singha Durbar, Kathmandu,Nepal vailable http://www.moac.gov.np/publications/statistics/new/New\%20Cereal\%20Crops.pdf

NMRP (National Maize Research Program). 2008. The Hill Maize Research Project (HMRP) End of Phase II report, January 2003-December 2007, National Maize Research Program (NMRP) and International Maize and Wheat Improvement Center (CIMMYT).

NSB (National Seed Board). 2009. List of different crop varieties released in Nepal (Nepali). National seed board, Hariharbhawan.

Paudyal, KR, JK Ransom, NP Rajbhandari, K Adhikari, RV Gerpacio and PL Pingali. 2001. Maize in Nepal: Production Systems, Constraints, and Priorities for Research. Kathmandu: NARC and CIMMYT.

Shrestha RP and M Thapa (Eds.). 2008. Proceedings of the fourth national seed seminar -2008. 19-20 June 2008. Lalitpur, National Seed Board, MoAC, Nepal. 